conserve species and habitats. What Works in Conservation 2018, the third edition of the What Works series from the Conservation Evidence project, is a digest of data from over 5,000 scientific tests of over 1,200 conservation interventions (actions of any sort that conservationists could take to protect biodiversity). Freely available from https:// www.openbookpublishers.com/product/696, the book summarizes the evidence available from https://www.conservationevidence.com.

This new edition is over $50 \%$ larger than that of last year, reflecting the number of new conservation interventions that have been summarized and assessed since then. Comprehensive new chapters have been added on the conservation of primates, shrublands and heathlands, and peatlands, as well as a chapter on management actions for some animal groups in captivity. The chapter on control of freshwater invasive species has been extended since 2017 to cover additional invasive species, and the other chapters from previous editions cover global conservation of amphibians, bats, birds and forests, conservation of European farmland biodiversity, and some aspects of enhancing natural pest control and soil fertility.

The book uses expert assessment, elicited over two rounds of Delphi scoring, to score interventions using a traffic light system. This scoring system comprises three components, (effectiveness of the intervention, certainty of the evidence, and harms arising from the intervention), and the scores from these components are combined to give each intervention a category ranging from 'Beneficial' to 'Likely to be ineffective or harmful'. It also identifies where the evidence is insufficient to make such judgements. For those who desire greater detail, links to the more indepth evidence describing each individual study are provided.

The interventions covered include species and habitat management strategies, but go beyond this to include interventions on livelihood, economic and other incentives; education and awareness; law and policy; and land/water protection. This gives the reader an overview of a wide range of available conservation techniques they could try, and the evidence for how well each has worked. The book also highlights what we do not know: where the team found no studies for an intervention this is indicated, providing a useful indication to researchers of where to target future efforts. For example, for bats 48 of the 78 interventions reviewed returned no studies, and for primates a third of interventions had been tested but as a result of insufficient or unclear evidence they were classed as 'Unknown effectiveness'. If researchers systematically tested the interventions with the least evidence, we'd soon learn a lot more about how to conserve the natural world more effectively.

The concept of evidence-based conservation is often promoted without sufficient consideration of how conservationists are expected to ensure their work is evidence-based. This book is one easy way in which practitioners and policy-makers can assess the degree to which their decisions align with current evidence, making it practical to turn a paradigm into a reality.

Claire Wordley, Silviu Petrovan, Rebecca Smith, Lynn Dicks, NANCY OCKENDON and WILLIAM SUTHERLAND Conservation Evidence, The University of Cambridge, UK Emailcfw41@cam.ac.uk

\section{Discovery of two new populations of the rare endemic Rhododendron liboense in Guizhou, China}

The Yunnan-Kweichow Plateau in Guizhou, China, is famous for its plant diversity. However, unlike in Yunnan, where there have been many explorations for plants, large areas in Guizhou remain to be investigated. Rhododendron liboense Z. R. Chen \& K. M. Lan, an evergreen tree of the Ericaceae family, is only known from a single population of 35 individuals growing on a karst mountain in Libo county, south-east Guizhou. It was categorized as Critically Endangered on the Red List of Rhododendrons (Gibbs et al., 2011, The Red List of Rhododendrons, Botanic Gardens Conservation International), and as Critically Endangered on the Chinese Higher Plants Red List (Qin et al., 2017, Biodiversity Science, 25, 696-744).

To secure more information on $R$. liboense three field surveys were carried out in Libo County during 2017-2018 with the support of Botanic Gardens Conservation International (grant no. BGCI30415). In addition to the type location on Donghua mountain in Maolan National Nature Reserve, two additional populations of $R$. liboense were located. In April 2017 a population of 15 plants (with four flowering) was found in Xizhu, c. $10 \mathrm{~km}$ from the type location of $R$. liboense. In March 2018 a population of 36 plants (with 23 flowering) was found in Dongdao, c. $20 \mathrm{~km}$ from the type location. These finds bring the total number of known individuals to 86 . The habitat of the two newly located populations is similar to that of the type location, where $R$. liboense grows on steep karst mountains, but outside Maolan National Nature Reserve.

In addition, 300 seedlings of $R$. liboense, propagated from seeds collected from the Donghua population in November 2016, are available for ex situ conservation. At least 100 seedlings will be planted in 2018 in the Rhododendron garden of Guizhou Minzu University, to assess adaptation. Given the species' apparently low fruit production and that two of the three known populations are unprotected, additional in situ conservation is required for this rare endemic Rhododendron. We are now discussing with local government officials potential in situ conservation actions for populations of $R$. liboense outside Maolan National Nature 
Reserve. Research on the pollination biology and population genetics of $R$. liboense is planned, to support the conservation of the species.

Hunng Chengling and Su Chunhua College of EcoEnvironmental Engineering,Guizhou Minzu University, Guiyang, Guizhou, China.E-mail chenglinghuang@163.com

Tian XIaOling College of Humanities \& Sciences, Guizhou Minzu University, Guiyang, Guizhou, China

CHEN ZHENREN Administration Department of Maolan National Nature Reserve, Libo, China

WEN XIANGYING South China Botanical Garden, the Chinese Academy of Sciences, Guangzhou, China

\section{New legislation threatens wildlife conservation in Poland}

In April 2018 a new Hunting Law (Journal of Laws of the Republic of Poland, 30 March 2018, No. 651) entered into effect in Poland. Poland is one of the last four countries in the EU (in addition to Croatia, Malta and Cyprus) that do not regulate the use of toxic lead ammunition. Each year 400$640 \mathrm{t}$ of lead are introduced into the Polish environment (Niech Żyją, 22 January 2017, http://niechzyja.pl/dokumenty/uwagi-do-zmiany-prawa-lowieckiego-2015.pdf; Kitowski et al., 2017, Ambio, 46, 825-841). Consequently, high concentrations of lead are found in Polish raptors that consume wounded game species or carrion (Komosa \& Kitowski, 2008, Ecological Chemistry and Engineering S, 15, 349-358; Kitowski et al., 2017, op. cit.). The new Hunting Law has not enacted a ban on lead ammunition in any habitat, even in wetlands. There is still no obligation to register animals embedded with lead ammunition that are not recovered. Attempts to ban lead ammunition in Poland so far have been unsuccessful, even though in 2013 Parliament declared that lead ammunition would be banned from hunting shoots on wetlands by 2015 (Polish Parliament 2017, 24 October 2017; http://sejm.gov.pl/sejm7. nsf/InterpelacjaTresc.xsp?key=02849767).

The new Hunting Law ignores current population trends and the status of game birds because cultivation of hunting traditions was considered an important factor in placing individual bird species on the list of game animals that can be legally hunted. This opens up the possibility of unlimited exploitation of species whose numbers are decreasing at an alarming rate in Poland. This applies in particular to the hazel grouse Bonasa bonasia (population 15,000-20,000 pairs in Poland) and Eurasian teal Anas crecca (population 1,300-1,700 pairs; Chodkiewicz et al., 2015, Ornis Polonica, $56,149-189)$. Hunters have already greatly reduced the western capercaillie Tetrao urogallus (population 400-450 adults) and black grouse Lyrurus tetrix (population 250300 pairs), which, despite being protected since 1995, are Critically Endangered species in Poland (Mitrus \& Zbyryt, 2015, Ornis Polonica, 56, 309-327).

Although the new Hunting Law prohibits group hunting in national parks, the Act of 11 March 2004 (amended in July 2017; Journal of Laws of the Republic of Poland, 9 August 2017, No. 1521) on the protection of animal health and the control of infectious diseases in animals legalized this practice within national parks and nature reserves under the pretense of combating African Swine Fever (Pejsak \& Woźniakowski, 2017, Życie Weterynaryjne, 92, 648-651). However, group hunting can contribute to the spread of this disease (Pejsak \& Woźniakowski, 2017, op. cit.).

The Polish Hunter Association (Polski Związek Łowiecki) oversees hunting activities de facto and de jure in Poland. The Association is connected with political and financial elites, and many powerful representatives of the media and business are members. The lobbying centre for the Association within the Polish Parliament (the Parliamentary Team on Culture and Tradition of Hunting) includes 32 deputies and three senators. The strong position of the Association in Parliament makes it difficult to change regulations in favour of wildlife conservation.

IGNACY KITOWSKI State School of Higher Education in Chetm, Chetm, Poland.E-mail ignacyk@autograf.pl

\section{New report of Eurasian otters in Lao}

There is little information on otters in Lao although there are three reported species: smooth-coated otter Lutrogale perspicillata, Asian small-clawed otter Aonyx cinereus and Eurasian otter Lutra lutra. It is also possible that the hairynosed otter Lutra sumatrana is present as it has been found in neighbouring countries (Thailand, Myanmar, Viet Nam and Cambodia).

There were formerly only two recent sources of information on otters in Lao. In 2016 Project Anoulak, a local NGO, produced a report on a preliminary camera-trap survey in the Nakai Nam Theun National Protected Area. In addition to camera-trap surveys, they interviewed local people who provided information on two species locally: 'one with feet like dogs, small and dark, mostly seen in groups of 3-5 individuals' (the Asian small-clawed otter), and 'one with feet like ducks, large, mostly seen in pairs' (the smooth-coated otter). They did not receive reports of the Eurasian otter. The other information came from the Wildlife Conservation Society in April 2018: they confirmed that rangers encounter otters relatively often on one river in the south-east of Nam Et Phou Louey National Park, but they do not know of which species. 